\title{
Study of Genotypic and Phenotypic Correlation among 20 Accessions of Nigerian Cowpea
}

\author{
Adetiloye I. $\mathrm{S}^{1}$., Ariyo O. $\mathrm{J}^{2}$ and Awoyomi O. L. ${ }^{1}$ \\ ${ }^{I}$ National Center for Genetic Resources and Biotechnology, Moor Plantation, Ibadan, Nigeria \\ ${ }^{2}$ Federal University of Agriculture, Abeokuta, Nigeria
}

\begin{abstract}
Morphological techniques were used to evaluate the diversity in 20 cowpea accessions collected from some parts of Nigeria for two years (2007 and 2008) at Ibadan, South Western Nigeria. Correlation analysis was employed to show the relationships among the traits. Similarly, genotypic and phenotypic variances, genotypic coefficients of variation, heritability and expected genetic advance were estimated for the twelve traits in cowpea for each season. This study shows that for cowpea yield improvement, number of main branches, pod numbers, pods per plant, pods per peduncle and seeds per pod should be part of the selection criteria.
\end{abstract}

Keywords: Cowpea, Correlation, Genoypic, Phenotypic, Accenssions, Diversity

\section{Introduction}

Cowpea is the most widely cultivated and utilized grain legume in Nigeria as well as one of the cheapest sources of plant protein sources in the diet of Nigerians providing over 57\% protein. Cowpea is cultivated for its seed (shelled green or dried), pods and/or leaves, which are consumed in fresh form as green vegetables, while snacks and main meal dishes are prepared from the dried grain. It is also a good substitution for animal protein.

Morphological traits is the first step in the genetic diversity studies in most breeding programmes (Cox and Murphy, 1990) because, The existing data bases on the germplasm collection or breeding stocks can often be used for genetic analysis. Grain yield is as a result of association of several trait and this makes yield a complex trait. Genotypic correlation coefficients provide a measure of the genotypic association between characters and give an indication of the characters that may be useful as indicators of more important ones under consideration.The success of most plant breeding programmes rely largely on the amount of diversity present in the population as the nature of genetic variability and its magnitude determine the selection criteria and breeding schemes to be used for improvement purposes. Understanding the extent, distribution and nature of this diversity would be useful in the breeding of cowpea genotypes with increased yield potential.

The objective of this study is to determine the level of association among the agronomic characters of cowpea accessions for the best use of the genetic potential of the crop and for a better management of cowpea germplasm and improvement of yield..

\subsection{Materials}

\section{Materials And Methodology}

\subsubsection{Plant materials}

The 20 accessions of Cowpea used for this study were collected from market places, farmer's fields' in various States in Nigeria and a breeding line (IFE BPC) (Table 1) during explorations. These collections have since been maintained in the ex-situ genebank of the National Centre for Genetic Resources and Biotechnology (NACGRAB), Ibadan, Nigeria.

\subsubsection{Location}

This study was carried out on the research farm of the National Centre for Genetic Resources and Biotechnology (NACGRAB), Ibadan. It is a forest savannah transition zone located on the longtitude $03^{\circ} 01^{\top} \mathrm{W}$ and latitude $07^{0}$ 22 'S.

\subsection{Methods}

The seeds were sown using Randomized Complete Block Design (RCBD) with three replications in single row plots to minimize environmental variations. Planting was done during the late season (August) of 2007 and 2008 in $4 \mathrm{~m}$ long rows with $60 \mathrm{~cm}$ inter-row and $40 \mathrm{~cm}$ intra-row spacing while blocks were separated from each other using $1 \mathrm{~m}$ spacing. Three seeds were sown per hole and were thinned to two plants per stand two weeks after planting (WAP), each row therefore, contained 20 plants and the 16 inner competitive plants within each row were utilized for observation. 
Weeding was done three (3) and six (6) weeks after planting (WAP) manually while insect pest was controlled using Karate at $50 \mathrm{ml}$ per 20 litres of water. Fertilizer was applied at the rate of $30 \mathrm{kgN} / \mathrm{ha}$ and $30 \mathrm{kgP} / \mathrm{ha}$ was applied as basal fertilizer in form of NPK 15:15:15 at one (1) week before planting. Data on the agronomic and morphological characters were collected from 10 randomly selected competitive plants from each of the 20 accessions of Cowpea and their means were recorded for all observations. Data from the 12 agro botanical traits from the 20 accessions were subjected to statistical analysis. Correlation analysis was employed to show the relationships among the traits.

\section{Results And Discussions}

The genotypic and phenotypic correlation coefficients among 12 cowpea agronomic characters in the year 2007 and 2008 planting seasons are presented in Table 1 and 2 respectively. Genotypic correlation coefficients provide a measure of the genotypic association between characters and give an indication of the characters that may be useful as indicators of more important ones under consideration. Generally, genotypic correlations were higher than the corresponding phenotypic ones.

This implied that the traits under consideration were genetically controlled. Similar observations were obtained on cowpea by Nakawuka and Adipala (1999). The closeness of phenotypic and genotypic correlation coefficients in some instances suggests that environment had some effect on the correlated characters.

The significant positive genotypic correlations between grain yield and number of main branches $(r=0.31,0.21)$, number of pods per peduncle $(r=0.64,0.72)$, the number of pods per plant $(r=0.58,0.57)$, pod length $(r=0.48,0.52)$, and number of seeds per pod $(r=0.55,0.72)$ suggest that these characters contributed positively towards yield and should be considered when selecting for high grain yield in cowpea. Similar results were reported by Ombakho and Tyagi (1987), and Okeleye et al, (1999). However, number of pods per peduncle $(r=0.64,0.72)$ and the number of pods per plant $(r=0.58,0.57)$ had the highest positive genotypic correlation with the grain yield, thus suggesting that the higher the number of pods per peduncle and number of pods per plant, the more the seed yield. The low and non-significant positive genotypic and phenotypic association between pod length and number of pods per plant $(r=0.01,0.16),(r=0.01,0.13$ respectively) would indicate that the selection of genotype for longer pods may not produce many pods per plant. The high positive correlation between number of seeds per pod and pod length $(r=0.58,0.46)$ indicates that with longer pods, more space is provided for seeds.

However, the high negative genotypic correlation between number of seeds per pod and 100 seed weight $(r=-0.41,-0.38)$ indicated that the more the seeds, the smaller the size. The decrease in seed size could lead to unacceptability of some cultivars, especially where large seeded cultivars are preferred. Also, the negative correlation between $50 \%$ flowering and number of pods per plant $(r=-0.27,0.08)$ suggests that early flowering would mean more time for grain filling which can translate to higher yield and bigger seed size than the late flowering cultivars since the number of pods per plant is highly correlated positively with the seed yield. The observed variation in all the traits considered in this study will enhance the genetic improvement of the crop for any of the characters evaluated. The high loadings of some characters such as terminal leaflet length, terminal leaflet width, number of main branches, number of nodes, number of pods per peduncle, number of pods per plant, plant height, seed weight and seed yield indicate their importance in delineating the collections.

The highest contributors to seed yield appear to be branch number, number of pods per peduncle, number of pods per plant and number of seeds per pod (Jackai, 1995 \& Aremu et al., 2007). Although earlier research showed that seed size is a primary determinant of yield in cowpea (Imrie and Bray, 1983, and Obisesan, 1985), this was not the case in the present study.

This discrepancy may have been due to the different genotypes used. Thus for cowpea yield improvement, number of main branches, pod numbers, pods per plant, pods per peduncle and seeds per pod should be part of the selection criteria. 
Study of genotypic and phenotypic correlation among 20 accessions of Nigerian cowpea

Table 1: Genotypic correlation coefficient among twelve characters of 20 cowpea accessions in year 2007 and 2008 seasons

\begin{tabular}{|c|c|c|c|c|c|c|c|c|c|c|c|c|}
\hline $50 \%$ flowering & 2007 & $0.50^{* *}$ & $0.31 *$ & -0.06 & -0.22 & -0.15 & $-0.27^{*}$ & 0.13 & -0.14 & 0.06 & -0.13 & $\backslash-0.07$ \\
\hline & 2008 & $0.58 * *$ & $0.39 * *$ & 0.14 & 0.17 & -0.02 & 0.08 & -0.12 & 0.20 & 0.01 & $-0.33^{* *}$ & 0.03 \\
\hline \multirow{2}{*}{ TLL $(\mathrm{cm})$} & 2007 & & $0.61^{* *}$ & 0.13 & 0.01 & 0.10 & 0.01 & $0.42 * *$ & $-0.38 *$ & $0.37^{* *}$ & $-0.51 * *$ & $0.49 * *$ \\
\hline & 2008 & & $0.81 * *$ & $0.34^{* *}$ & $0.47 * *$ & 0.03 & 0.19 & $0.34^{* *}$ & 0.08 & $0.37^{* *}$ & $-0.44 * *$ & $0.37^{* *}$ \\
\hline \multirow{3}{*}{ TLW $(\mathrm{cm})$} & & & & & & & & & & & & \\
\hline & 2007 & & & -0.02 & 0.19 & 0.11 & -0.11 & 0.14 & 0.04 & -0.01 & -0.02 & 0.09 \\
\hline & 2008 & & & $0.26^{*}$ & $0.37 * *$ & 0.15 & $0.29 *$ & $0.25^{*}$ & 0.13 & $0.33^{* *}$ & $-0.41^{* *}$ & $0.39 * *$ \\
\hline \multirow[t]{2}{*}{ NMB } & 2007 & & & & $0.74 * *$ & 0.24 & $0.70^{* * *}$ & -0.17 & 0.02 & $-0.41 * *$ & -0.05 & $0.31 *$ \\
\hline & 2008 & & & & $0.97 * *$ & -0.01 & $0.55^{* *}$ & 0.07 & $0.35^{* *}$ & -0.23 & -0.07 & 0.21 \\
\hline \multirow[t]{2}{*}{$\mathrm{NN}$} & 2007 & & & & & 0.14 & $0.48^{* *}$ & $-0.42^{* *}$ & 0.06 & $-0.38 * *$ & 0.01 & 0.15 \\
\hline & 2008 & & & & & 0.07 & $0.56^{* *}$ & 0.06 & $0.37^{* *}$ & -0.01 & -0.20 & $0.38^{* *}$ \\
\hline \multirow{3}{*}{ NPPD } & & & & & & & & & & & & \\
\hline & 2007 & & & & & & $0.83 * *$ & 0.11 & -0.19 & -0.06 & -0.15 & $0.64^{* *}$ \\
\hline & 2008 & & & & & & $0.84^{* *}$ & 0.18 & $0.51 * *$ & 0.15 & $-0.71^{* *}$ & $0.72 * *$ \\
\hline & & & & & & & & & & & & \\
\hline \multirow[t]{2}{*}{ NPPL } & 2007 & & & & & & & 0.01 & -0.06 & $-0.29 *$ & -0.06 & $0.58 * *$ \\
\hline & 2008 & & & & & & & 0.16 & $0.62^{* *}$ & -0.18 & $-0.62^{* *}$ & $0.57^{* *}$ \\
\hline & & & & & & & & & & & & \\
\hline \multirow[t]{2}{*}{$\mathrm{PL}(\mathrm{cm})$} & 2007 & & & & & & & & -0.15 & $0.58 * *$ & $-0.39 * *$ & $0.48 * *$ \\
\hline & 2008 & & & & & & & & -0.06 & $0.46^{* *}$ & -0.08 & $0.52 * *$ \\
\hline \multirow{2}{*}{$\mathrm{PH}(\mathrm{cm})$} & 2007 & & & & & & & & & $025 *$ & 023 & $020 \%$ \\
\hline & 2008 & & & & & & & & & $\frac{-0.23^{*}}{-0.03}$ & $\frac{0.23}{-0.25 *}$ & $\frac{-0.50 *}{0.43 * *}$ \\
\hline & & & & & & & & & & & & \\
\hline \multirow[t]{2}{*}{ NSP } & 2007 & & & & & & & & & & $-0.41^{* *}$ & $0.55^{* * *}$ \\
\hline & 2008 & & & & & & & & & & $-0.38^{* *}$ & $0.72^{* * *}$ \\
\hline & & & & & & & & & & & & \\
\hline \multirow[t]{2}{*}{ SW(g) } & 2007 & & & & & & & & & & & $-0.33^{*}$ \\
\hline & 2008 & & & & & & & & & & & $-0.61^{* *}$ \\
\hline
\end{tabular}

*,** Significant at $0.05,0.01$ probability levels respectively

TLL- Total Leaflet Length; TLW- Total Leaflet Width; NMB- Number of Main Branches; NN- Number of Nodes; NPPD- Number of Pods per Peduncle; NPPL- Number of Pods per Plant; PL- Pod Length; PH- Plant Height; NSP- Number of Seeds per Pod; SW- Seed Weight; SY- Seed Yield.

Table 2: Phenotypic correlation coefficient among twelve characters of 20 cowpea accessions in year 2007 and 2008 seasons

\begin{tabular}{|c|c|c|c|c|c|c|c|c|c|c|c|c|}
\hline Character (2007) & & $\pi \Psi(\mathrm{cm})$ & TLW $(\mathrm{cm})$ & NMB & $\mathrm{NN}$ & NPPD & NPPL & $P L(\mathrm{~cm})$ & $\mathrm{PH}(\mathrm{cm})$ & NSP & $\operatorname{sw}(g)$ & $S Y(g)$ \\
\hline \multirow[t]{2}{*}{$50 \%$ tlowering } & 2007 & $0.46^{*}$ & $0.30^{\circ}$ & -0.05 & -0.21 & -0.14 & $-0.26^{\circ}$ & 0.13 & -0.14 & 0.06 & -0.13 & -0.07 \\
\hline & 2008 & $0.55^{\mathrm{N*}}$ & $0.37 \%$ & 0.12 & 0.15 & -0.01 & 0.07 & 0.12 & 0.20 & 0.01 & $0.32^{\circ}$ & 0.03 \\
\hline \multirow[t]{2}{*}{$\pi L(\mathrm{~cm})$} & 2007 & & $0.54 * 0$ & 0.10 & 0.00 & 0.10 & 000 & $0.39 \cdots$ & $-0.35^{*}$ & $0.34^{\circ}$ & $-0.46^{* 0}$ & $0.42^{\cdots}$ \\
\hline & 2008 & & $0.76^{* *}$ & $0.34^{*}$ & $0.44^{* *}$ & 0.06 & 0.21 & $0.32^{\circ}$ & 0.04 & $0.35 \%$ & $0.41^{\cdots}$ & $0.37^{* 0}$ \\
\hline \multirow{3}{*}{$\pi \mathrm{W}(\mathrm{cm})$} & & & & & & & & & & & & \\
\hline & 2007 & & & -0.02 & 0.17 & 0.08 & -0.11 & 0.13 & 0.05 & -0.01 & -0.02 & 0.08 \\
\hline & 2008 & & & 0.22 & $0.34^{* *}$ & 0.13 & 0.22 & $0.25^{\circ}$ & 0.12 & $0.33 *$ & $-0.40^{\cdots}$ & $0.35 \%$ \\
\hline \multirow{2}{*}{ NMB } & 2007 & & & & $0.74^{\mathrm{x}}$ & 0.24 & $0.69 \times 2$ & 017 & 003 & $0.40 \%$ & 0.05 & 0.328 \\
\hline & 2008 & & & & $0.95 \%$ & 0.05 & $0.57 \%$ & 0.06 & $0.30^{\circ}$ & -0.20 & $\frac{0.03}{-0.06}$ & $0.26^{*}$ \\
\hline & & & & & & & & & & & & \\
\hline \multirow[t]{2}{*}{ NN } & 2007 & & & & & 0.14 & $0.48^{20}$ & $0.41 \%$ & 0.06 & $0.37 \%$ & 0.00 & 0.16 \\
\hline & 2008 & & & & & 0.08 & $0.53 \%$ & 0.06 & $0.34 \%$ & 0.00 & -0.18 & $0.39 \%$ \\
\hline & & & & & & & & & & & & \\
\hline \multirow[t]{2}{*}{ NPPD } & 2007 & & & & & & $0.81^{*}$ & 0.10 & -0.18 & -0.06 & -0.14 & $0.63 * 5$ \\
\hline & 2008 & & & & & & $0.83 * 0$ & 0.16 & $0.42^{* 0}$ & 0.13 & $-0.59 \times x$ & $0.71^{\times 7}$ \\
\hline & & & & & & & & & & & & \\
\hline \multirow[t]{2}{*}{ NPPL } & 2007 & & & & & & & 0.01 & -0.06 & $-0.28^{\circ}$ & -0.06 & $0.60^{* *}$ \\
\hline & 2008 & & & & & & & 0.13 & $0.51^{\times 0}$ & .0 .14 & $-0.49^{\times \mathrm{K}}$ & $0.62^{* x}$ \\
\hline & & & & & & & & & & & & \\
\hline \multirow[t]{2}{*}{$\mathrm{PL}(\mathrm{cm})$} & 2007 & & & & & & & & -0.15 & $0.57^{* 0}$ & $-0.39 * 0$ & $0.46 * 0$ \\
\hline & 2008 & & & & & & & & 0.06 & $0.46^{\mathrm{N*}}$ & 0.07 & $0.47^{* n}$ \\
\hline & & & & & & & & & & & & \\
\hline \multirow{2}{*}{ PH $(\mathrm{cm})$} & 2007 & & & & & & & & & -0.24 & 0.23 & $-0.29^{*}$ \\
\hline & 2008 & & & & & & & & & .0 .03 & $0.25^{*}$ & $0.3 \mathrm{~g}^{* 5}$ \\
\hline & & & & & & & & & & & & \\
\hline \multirow[t]{2}{*}{ NSP } & 2007 & & & & & & & & & & $-0.40 \cdots$ & $0.53^{* 0}$ \\
\hline & 2008 & & & & & & & & & & $0.38^{* t}$ & $0.66^{* *}$ \\
\hline & & & & & & & & & & & & \\
\hline \multirow[t]{2}{*}{$S W(g)$} & 2007 & & & & & & & & & & & $-0.32^{\mathrm{s}}$ \\
\hline & 2008 & & & & & & & & & & & $-0.55 *$ \\
\hline
\end{tabular}


TLL- Total Leaflet Length; TLW- Total Leaflet Width; NMB- Number of Main Branches; NN- Number of Nodes; NPPD- Number of Pods per Peduncle; NPPL- Number of Pods per Plant; PL- Pod Length; PH- Plant Height; NSP- Number of Seeds per Pod; SW- Seed Weight; SY- Seed Yield.

\section{Conclusions and Recommendations}

This study shows the presence of genetic variability among the Nigerian cowpea germplasm which can be used to broaden the genetic basis of the crop for better use of its genetic potential. For cowpea yield improvement, number of main branches, pod numbers, pods per plant, pods per peduncle and seeds per pod should be part of the selection criteria based on the result of this study.

These results of this research indicate that the traits/characters that correlated positively could effectively be utilized and considered when planning crop improvement program in cowpea.

\section{References}

[1]. Aremu, C. O., Adebayo, M. A., Ariyo, O. J., and Adewale, B. B., 2007. Classification of genetic diversity and choice of parents for hybridization in cowpea Vigna unguiculata (L.) Walp for humid savanna Ecology. African Journal of Biotechnology Vol. 6 (20): 2333-2339.

[2]. Cox, T. S. and Murphy, J. P. 1990. The effect of parental divergence on F2 heterosis in winter wheat crosses. Theoretical and Applied Genetics 79: 241-250.

[3]. IBPGR, 1983. International Board for Plant Genetic Resources Cowpea descriptor. Rome, Italy. 5-15

[4]. Imrie, B. C. and Bray, R. A. 1983. Estimates of combining ability and variance components of grain yield and associated characters in cowpea. Proceeding of Australian Plant Breeding Conference, 202-204.

[5]. Jackai, L.E.N. 1995. The legume pod borer Maruca vitrata, and its principal host plant, Vigna unguiculata (L.) Walp. Use of selective insecticide sprays as an aid in the identification of useful levels of resistance. Crop Protection 14:299-306.

[6]. Nakawuka, C. K. and Adipala, E. 1999. A path coefficient analysis of some yield component interaction in cowpea. Crop Science; 7: 327-331.

[7]. Obisesan, I. O. 1985. Associations among grain yield components in cowpea (Vigna unguiculata L. Walp). Genetica Agraria 39:377-386.

[8]. Okeleye, K. A., Ariyo, O. J. and Olowe, V. I. 1999. Evaluation of early and medium duration cowpea (Vigna unguculata (L) Walp) cultivars for agronomic traits and grain yield. Nigerian Agric J. (30), 1-11.

[9]. Ombakho, G. A. and Tyagi, A. P. 1987. Correlation and Path Coefficient Analysis for Yield and Its Components in Cowpea (Vigna unguiculata). East African Agric and Forestry J., 53. 23-37.

[10]. SAS Institute Inc. 1999. Statistic Analysis System. Version 8.0. SAS Institute Inc. Cary. NC, USA. 